\title{
Predictors of Psychosocial Burden among Workers During the COVID-19 Pandemic Period in Indonesia
}

\author{
Hario Megatsari ${ }^{1}$, Agung Dwi Laksono², Mursyidul Ibad ${ }^{3}$, Yeni Tri Herwanto ${ }^{4}$, \\ Kinanty Putri Sarweni ${ }^{4}$, Rachmad Ardiansyah Pua Geno ${ }^{4}$, Estiningtyas Nugraheni ${ }^{4}$ \\ ${ }^{1}$ Faculty of Public Health, Universitas Airlangga, Surabaya, Indonesia, ${ }^{2}$ Researcher, National Institute of Health \\ Research and Development, the Indonesian Ministry of Health, Jakarta, Indonesia, ${ }^{3}$ Researcher, Faculty of Health, \\ Nadlatul Ulama University, Surabaya, Indonesia, ${ }^{4}$ Researcher, The Indonesian Public Health Union, Makassar, \\ Indonesia.
}

\begin{abstract}
Psychosocial burden as a result of the risk of decreasing income and the possibility of being laid off from work is a problem that must be faced by workers during the COVID-19 pandemic. The study was aimed at analyzing predictors of psychosocial burden among workers during the co- 19 pandemic period. A total of 6,053 worker respondents were involved in this study. The psychosocial burden was reviewed based on the worries level. There were 4 independent variables involved in the analysis, including age, gender, marital, and education. A multivariate test was performed using binary logistic regression. The results found that the workers in the $\leq 19$ age group were 1.900 times more likely than the $\geq 50$ age group to experience a psychosocial burden. The workers in the 40-49 age group were 1.523 times more likely than the $\geq 50$ age group. Male workers were 0.693 times more likely than female workers to experience a psychosocial burden. The higher education workers were 0.563 times more likely than workers with secondary education. It could be concluded that the 3 variables were proven as predictors of the psychosocial burden among workers during the COVID-19 pandemic period in Indonesia, namely age, gender, and education.
\end{abstract}

Keywords: Mental health, workers, psychosocial burden, health behavior, COVID-19.

\section{Introduction}

The pandemic of COVID-19 is not going to end very soon shortly. There are some arguments to support the statement. The most recent number of COVID-19 cases in the world indicate that the number of new cases was increasing in the past 7 days from July $9^{\text {th, }} 2020$ to July $16^{\text {th, }} 2020$. The detailed information can be accessed in the www.worldometers.info/coronavirus/. Based on the website, it was also informed that the mortality rate of this disease was around $7 \%$ at the global level.

\footnotetext{
Corresponding Author:

Hario Megatsari

Faculty of Public Health, Universitas Airlangga, Surabaya, Indonesia

e-mail: hario.megatsari@fkm.unair.ac.id
}

The number of COVID-19 cases in Indonesia has not decreased trend. It can be seen on the official website of the government, namely www.covid19.go.id. Based on the website accessed on July $15^{\text {th }}, 2020$, the number of COVID-19 cases in Indonesia spread all over the province and district/city. And there is no indication the outbreak will end soon ${ }^{1}$.

The Indonesia government has taken several strategies to stop the chain of transmission of COVID-19. Some of the strategies are issuing Minister of Health Regulation No. 9 of 2020 concerning Large-Scale Social Limitation Guidelines in the context of accelerating the handling of COVID-19. The regulation regulates the restrictions that must be obeyed by the society. These restrictions include schools being closed, public transportation stopped, work from home, and so on. The main idea of the regulation is to lessen the movement of the community ${ }^{2,3}$. 
The impact of these regulations and restrictions have an impact on all sectors of social life, namely religious aspects, economic aspects, aspects of education, and aspects of social psychology. This can be seen from the many facts reported by the mass media about the impact of these restrictions, including the existence of a group of people who still have to work even though the regulation has been enforced in their territory ${ }^{4}$. The longer the Large Scale Social Restrictions, the more violations committed by the community ${ }^{5}$.

The limitation of community mobility during COVID-19 can potentially trigger anxiety in the form of depression and stress on society ${ }^{6,7}$. Anxiety is also reported because of the health beliefs that originate from the large amount of hoax information scattered on social media, which worsens the atmosphere ${ }^{8-10}$. The situation of the mass psychology getting worse due to the theory of conspiracy echoed by celebrities and influencers ${ }^{11,12}$, including conspiracy theories believed by the president of the USA, Donald Trump, as a form of celebrities and influencers resistance to the existence of the power of his government ${ }^{13}$.

Public anxiety can lead to new public health problems. WHO defines health as a good condition in 3 dimensions of human life, namely the physical, social, and mental dimensions ${ }^{14}$. Anxiety is included in an unhealthy condition in WHO's perspective, so special attention is needed to pay close attention to the community's situation, especially in the current outbreak of COVID-19.On the other hand, the rate of unemployment during COVID-19 was increasing due to the situation of pandemic ${ }^{15,16}$. Based on the background description, this study is intended to analyze the predictors of psychosocial burden among workers during the COVID-19 pandemic period in Indonesia.

\section{Materials and Method}

The study was conducted by collecting data through online surveys of people who claimed to have jobs, who are domiciled throughout Indonesia. Data collection was carried out for 8 days (June 6-13, 2020). A total of 6,053 worker respondents were included in this analysis.

Psychosocial burden variables were arranged based on the worries level. The worries level was built based on the assessment of anxiety in 5 aspects of daily life, namely economic, religious, educational, employment, and social aspects. The questions in the questionnaire were arranged with five answer choices (Likert scale). Assessment of the worries level by adding up scores from 5 aspects measured, then dividing it into 2 categories of psychosocial burden, which were not worried and worried.

Four independent variables were included in the analysis. The four variables are age group, gender, marital status, education level. Age group was the respondent's acknowledgment of the last birthday that has passed. Age groups were divided into 6 categories, namely $\leq 19,20-29,30-39,40-49$, and $\geq 50$. Gender was divided into 2 categories, namely male and female. Marital status consists of 3 categories, namely single, married, and divorced/widowed. Education level was the respondent's recognition of the level of education that has been passed. Education level was divided into 2 categories, namely secondary and below, and higher.

The variables involved in this study, both dependent and independent, were dichotomous variables. Researchers used the bivariate test at an early stage with the Chi-Square test. This initial test was to select the independent variables that will be included in the next test phase. The multivariate test at the final stage was carried out using binary logistic regression to determine the predictors of psychosocial burden among workers during the COVID-19 pandemic period in Indonesia. All stages of analysis in this study were carried out with the help of SPSS software version 22.

\section{Results and Discussion}

Table 1 is a display of descriptive statistics of the characteristics of worker respondents. It can be seen that workers who have a psychosocial burden are dominated by workers who are in the age group of 20-29 and have female gender.

Based on marital status, the married workers dominate groups that have a psychosocial burden. While based on education level, the workers who have higher education dominate both categories of the psychosocial burden.

Information about the result of the binary logistic regression of psychosocial burden among workers during the COVID-19 pandemic period in Indonesia is presented in Table 2. All selected variables are included in this final analysis. 
Table 1. Descriptive Statistics of Respondent Characteristics $(n=6,053)$

\begin{tabular}{|c|c|c|c|c|c|}
\hline \multirow{3}{*}{ Variables } & \multicolumn{4}{|c|}{ The psychosocial burden } & \multirow{3}{*}{$\mathbf{P}$} \\
\hline & \multicolumn{2}{|c|}{ Not worried } & \multicolumn{2}{|c|}{ Worried } & \\
\hline & $\mathbf{n}$ & $\%$ & $\mathbf{n}$ & $\%$ & \\
\hline Age groups & & & & & $* * *<0.001$ \\
\hline$\leq 19$ & 16 & $1.7 \%$ & 131 & $2.6 \%$ & \\
\hline $20-29$ & 234 & $25.2 \%$ & 2028 & $39.6 \%$ & \\
\hline $30-39$ & 238 & $25.6 \%$ & 1401 & $27.3 \%$ & \\
\hline $40-49$ & 229 & $24.7 \%$ & 992 & $19.4 \%$ & \\
\hline$\geq 50$ & 211 & $22.7 \%$ & 573 & $11.2 \%$ & \\
\hline Gender & & & & & $* * *<0.001$ \\
\hline Male & 414 & $44.6 \%$ & 1716 & $33.5 \%$ & \\
\hline Female & 514 & $55.4 \%$ & 3409 & $66.5 \%$ & \\
\hline Marital status & & & & & $* * *<0.001$ \\
\hline Single & 242 & $26.1 \%$ & 1861 & $36.3 \%$ & \\
\hline Married & 652 & $70.3 \%$ & 3110 & $60.7 \%$ & \\
\hline Divorced/Widowed & 34 & $3.7 \%$ & 154 & $3.0 \%$ & \\
\hline Education level & & & & & $* * *<0.001$ \\
\hline Secondary and below & 160 & $17.2 \%$ & 1609 & $31.4 \%$ & \\
\hline Higher & 768 & $82.8 \%$ & 3516 & $68.6 \%$ & \\
\hline
\end{tabular}

Note: ${ }^{*} \mathrm{p}<0.05 ;{ }^{* *} \mathrm{p}<0.01 ;{ }^{* * *} \mathrm{p}<0.001$.

Table 2. The result of binary logistic regression of psychosocial burden(the worries level) of community in Indonesia, $2020(n=6,053)$

\begin{tabular}{|c|c|c|c|c|}
\hline \multirow{2}{*}{ Variables } & \multicolumn{4}{|c|}{ The psychosocial burden } \\
\hline & Sig & OR & Lower Bound & Upper Bound \\
\hline Age groups: $\leq 19$ & $* 0.041$ & 1.900 & 1.026 & 3.519 \\
\hline Age groups: $20-29$ & $* * *<0.001$ & 2.652 & 1.999 & 3.518 \\
\hline Age groups: $30-39$ & $* * *<0.001$ & 1.992 & 1.607 & 2.470 \\
\hline Age groups: $40-49$ & $* * *<0.001$ & 1.523 & 1.227 & 1.889 \\
\hline Age groups: $\geq 50$ & - & - & - & - \\
\hline Gender: Male & $* * *<0.001$ & 0.693 & 0.598 & 0.803 \\
\hline Gender: Female & - & - & - & - \\
\hline Marital status: Single & - & - & - & - \\
\hline Marital status: Married & 0.112 & 1.210 & 0.957 & 1.532 \\
\hline Marital status: Widowed/Divorced & 0.690 & 1.094 & 0.702 & 1.706 \\
\hline Education Level: Secondary & - & - & - & - \\
\hline Education Level: Higher & $* * *<0.001$ & 0.563 & 0.458 & 0.692 \\
\hline
\end{tabular}

Note: ${ }^{*} \mathrm{p}<0.05 ;{ }^{* *} \mathrm{p}<0.01 ;{ }^{* * *} \mathrm{p}<0.001$. 
Table 2 shows that the workers in the $\leq 19$ age group were 1.900 times more likely than the $\geq 50$ age group to experience a psychosocial burden (OR 1.900; 95\% CI 1.026-3.519). The workers in the 20-29 age group were 2.652 times more likely than the $\geq 50$ age group to experience a psychosocial burden (OR 2.652; $95 \%$ CI 1.999-3.518). The workers in the 30-39 age group were 1.992 times more likely than the $\geq 50$ age group to experience a psychosocial burden (OR 1.992; 95\% CI 1.607-2.470). The workers in the 40-49 age group were 1.523 times more likely than the $\geq 50$ age group to experience a psychosocial burden (OR 1.523; 95\% CI 1.227-1.889). Information from the results of this analysis shows that age is a predictor of psychosocial burden among workers during the COVID-19 pandemic period in Indonesia. The workers who have the oldest age have the lowest possibility to experience psychosocial burdens.

Age as a predictor of psychosocial burden is also reported in several studies in various countries ${ }^{17-19}$. Older age is directly proportional to more life experiences. The senior workers have a more coping mechanism in dealing with uncertain situations during the COVID-19 pandemic period ${ }^{20,21}$.

Table 2 informs that male workers are 0.693 times more likely than female workers to experience psychosocial burden (OR 0.693; 95\% CI 0.598-0.803). The results of this analysis indicate that gender is a predictor of psychosocial burden among workers during the COVID-19 pandemic period in Indonesia. The female workers have a higher chance of experiencing psychosocial burden.

Consistent information was also found in previous studies. The female group was reported to have more potential to experience mental disorders in the form of depression and anxiety compared to the male group ${ }^{22}$. Male workers are considered more able to cope with uncertainty pressures during the pandemic than female workers ${ }^{23}$.

Table 2 shows that workers with higher education are 0.563 times more likely than workers with secondary education to experience psychosocial burden (OR 0.563 ; 95\% CI 0.458-0.692). This information shows that education level is a predictor of psychosocial burden among workers during the COVID-19 pandemic in Indonesia. Higher education has a lower probability of experiencing psychosocial burden.

Better education is directly proportional to the ability of workers to respond to the COVID-19 pandemic situation. Educational factors make a person able to understand information and digest the situation better so that they are better prepared to deal with uncertain situations during the COVID-19 pandemic ${ }^{24,25}$. Several previous studies inform that education is often found as a positive predictor of health sector performance ${ }^{26-28}$.

\section{Conclusions}

Based on the results of the analysis it could be concluded that 3 variables were proven to be predictors of the psychosocial burden among workers during the co-19 pandemic period in Indonesia. The four variables were age group, gender, and education level.

Acknowledgments: The author would like to thank all the Persakmi and IKA Airlangga Surabaya who have allowed the use of online survey data about this psychosocial.

\section{Source of Funding: Self-funding}

Conflict of Interest: The authors declare no conflict of interest, financial or otherwise.

Ethical Clearance: This study of the psychosocial burden of community during the COVID-19 pandemic period in Indonesia has received ethical approval from the national ethics commission (No: RK.05/KEPK/ STIK/VIK/2020). The respondents' identities have all been deleted from the dataset. Respondents have provided written approval for their involvement in the study.

\section{References}

1. Hoseinpour Dehkordi A, Alizadeh M, Derakhshan P, Babazadeh P, Jahandideh A. Understanding epidemic data and statistics: A case study of COVID-19. J Med Virol. 2020;92(7):868-82.

2. Task Force for the Acceleration of Handling COVID-19. COVID-19 Health Handling Protocol (Protokol Kesehatan Penanganan COVID-19) [Internet]. Indonesia; 2020 p. 1-10. Available from: https://covid19.go.id/p/protokol/protokolkesehatan-penanganan-covid-19

3. Laksono AD, Wulandari RD, Ibad M, Herwanto YT, Sarweni KP, Geno RAP, et al. Predictors of Healthy Lifestyle in The COVID-19 Pandemic Period in East Java, Indonesia. J Crit Rev. 2020;7(18):1515-21. 
4. Laksono AD, Ibad M, Herwanto YT, Sarweni KP, Geno RAP, Nugraheni E. Evaluation of the Implementation of Large Scale Social Restrictions in East Java, Indonesia (Evaluasi Pelaksanaan Pembatasan Sosial Berskala Besar di Jawa Timur, Indonesia) [Internet]. Surabaya; 2020. Available from: https:/www.researchgate.net/ publication/342053442_Evaluasi_Pelaksanaan_ Pembatasan_Sosial_Berskala_Besar_di_Jawa Timur

5. Ibad M, Laksono AD, Herwanto YT, Sarweni KP, Geno RAP, Nugraheni E. East Java Needs "Public Health" Police (Jawa Timur Perlu Polisi "Kesehatan Masyarakat") [Internet]. Surabaya; 2020. Available from: https://www. researchgate.net/publication/341627090_JAWA_ TIMUR_PERLU_POLISI_KESEHATAN MASYARAKAT

6. Bohlken J, Schömig F, Lemke MR, Pumberger M, Riedel-Heller SG. COVID-19 Pandemic: Stress Experience of Healthcare Workers: A Short Current Review. Psychiatr Prax. 2020;47(4):190-7.

7. Fawaz M, Samaha A. The psychosocial effects of being quarantined following exposure to COVID-19: A qualitative study of Lebanese health care workers. Int J Soc Psychiatry. 2020;In press:In press.

8. Costa MF da. Health belief model for coronavirus infection risk determinants. Rev Saude Publica. 2019;54(47):1-12.

9. Athbi HA, Hassan HB. Health Beliefs of Patients with Coronary Heart Disease toward Secondary Prevention: The Health Beliefs Model as a Theoretical Framework. Indian J Public Heal Res Dev. 2019;10(1):272-8.

10. Evans G. Questions: COVID-19 mortality, conspiracy theories, and the mysterious lack of sick children: "Flu has a mortality of $0.1 \%$ - This has a mortality 10 times that." Hosp Infect Control Prev. 2020;47(4):1.

11. Task Force for the Acceleration of Handling COVID-19. Hoax Buster [Internet]. Jakarta; 2020. Available from: https://covid19.go.id/p/hoaxbuster

12. Meiryani, Siagian $P$, Lusianah, Lesmana $T$. Technology's role to avoid the spread of COVID-19. Int J Psychosoc Rehabil. 2020;24(7):9902-9.

13. Dyer O. Trump claims public health warnings on covid-19 are a conspiracy against him. BMJ. 2020;BMJ (Clini:m941.

14. World Health Organization. Preamble to the Constitution of WHO. New York, Geneva; 1946.

15. Sri Kasnelly FAJ. MENINGKATNYA ANGKA PENGANGGURAN DITENGAH PANDEMI (COVID-19). Al-Mizan J Ekon Syariah. 2020;3(1).

16. Tran BX, Vu GT, Latkin CA, Pham HQ, Phan HT, Le HT, et al. Characterize health and economic vulnerabilities of workers to control the emergence of COVID-19 in an industrial zone in Vietnam. Saf Sci. 2020;129:Article number 104811.

17. Gualano MR, Lo Moro G, Voglino G, Bert F, Siliquini R. Effects of COVID-19 lockdown on mental health and sleep disturbances in Italy. Int $\mathrm{J}$ Environ Res Public Health. 2020;17(13):1-13.

18. Mazza C, Ricci E, Biondi S, Colasanti M, Ferracuti $\mathrm{S}$, Napoli C, et al. A nationwide survey of psychological distress among italian people during the covid-19 pandemic: Immediate psychological responses and associated factors. Int J Environ Res Public Health. 2020;17(9):Article number 3165.

19. Dubey S, Biswas P, Ghosh R, Chatterjee S, Dubey MJ, Chatterjee S, et al. Psychosocial impact of COVID-19. Diabetes Metab Syndr Clin Res Rev. 2020;14(5):779-88.

20. Ozamiz-Etxebarria N, Idoiaga Mondragon N, Dosil Santamaría M, Picaza Gorrotxategi M. Psychological Symptoms During the Two Stages of Lockdown in Response to the COVID-19 Outbreak: An Investigation in a Sample of Citizens in Northern Spain. Front Psychol. 2020;11:Article number 1491.

21. Ozamiz-Etxebarria N, Dosil-Santamaria $M$, Picaza-Gorrochategui $\mathrm{M}$, Idoiaga-Mondragon $\mathrm{N}$. Stress, anxiety, and depression levels in the initial stage of the COVID-19 outbreak in a population sample in the northern Spain. Cad Saude Publica. 2020;36(4):Article number e00054020.

22. Kiely KM, Brady B, Byles J. Gender, mental health and ageing. Maturitas. 2019;129:76-84.

23. Ballering AV, Bonvanie IJ, Olde Hartman TC, Monden R, Rosmalen JGM. Gender and sex independently associate with common somatic symptoms and lifetime prevalence of chronic disease. Soc Sci Med. 2020;253:Article number 112968.

24. Roy D, Tripathy S, Kar SK, Sharma N, Verma SK, 
Kaushal V. Study of knowledge, attitude, anxiety $\&$ perceived mental healthcare need in Indian population during COVID-19 pandemic. Asian J Psychiatr. 2020; In press: Article number 102083.

25. Chen Q, Min C, Zhang W, Wang G, Ma X, Evans R. Unpacking the black box: How to promote citizen engagement through government social media during the COVID-19 crisis. Comput Human Behav. 2020;110:Article number 106380.

26. Wulandari RD, Laksono AD. Education as predictor of the knowledge of pregnancy danger signs in Rural Indonesia. Int J Innov Creat Chang. 2020;13(1):1037-51.

27. Wulandari RD, Laksono AD. Determinants of knowledge of pregnancy danger signs in Indonesia. PLoS One. 2020;15(5):Article number e 0232550.

28. Ipa M, Widawati M, Laksono AD, Kusrini I, Dhewantara PW. Variation of preventive practices and its association with malaria infection in eastern Indonesia: Findings from community-based survey. PLoS One. 2020;15(5):e0232909. 